\title{
APLIKASI BERAS KETAN HITAM (Oryza sativa var glutinous) DAN MADU SEBAGAI BAHAN DASAR PEMBUATAN BODYSCRUB
}

\author{
Nina Hairiyah dan Nuryati \\ Jurusan Teknologi Industri Pertanian, Politeknik Negeri Tanah Laut \\ Email: ninahairiyah@politala.ac.id
}

\begin{abstract}
ABSTRAK
Bodyscrub adalah salah satu produk yang menjadi andalan konsumen dalam menjaga kebersihan dan kesegaran kulit tubuh, bodyscrub berfungsi untuk mengangkat sel-sel kulit mati, kotoran pada kulit dan membuka pori-pori sehingga kulit menjadi lebih cerah dan putih. Penelitian ini bertujuan untuk menentukan formulasi terbaik pada pembuatan bodyscrub berbahan dasar beras ketan hitam dan madu. Penelitian ini menggunakan metode analisis deskriptif dengan sampel beras ketan hitam dan madu. Pengujian yang dilakukan adalah pengamatan terhadap sifat fisik organoleptik (warna, aroma dan tekstur), kelembaban kulit, iritasi kulit, $\mathrm{pH}$ dan stabilitas emulsi. Hasil penelitian menunjukkan bahwa formulasi terbaik adalah bodyscrub dengan formulasi 4,6\% beras ketan hitam dan madu yang memiliki warna mauve, aroma sedikit berbau khas beras ketan hitam dan madu, tekstur lebih banyak butiran $s c r u b, \mathrm{pH} 7$, tidak terjadi iritasi kulit, nilai rata-rata kadar kelembaban kulit sebesar 18,60\%, dan stabilitas emulsi sebesar 79,72\%.

Kata kunci-beras ketan hitam (Oryza sativa var glutinous); bodyscrub; madu
\end{abstract}

\section{PENDAHULUAN}

Beras ketan dibedakan menjadi dua macam, yaitu beras ketan putih dan beras ketan hitam. Perbedaan warna ini tergantung dari pigmen yang terkandung didalamnya. Beras ketan hitam mengandung pigmen antosianin yang berwarna ungu pekat. Beras ketan hitam (Oryza sativa var glutinous) merupakan salah satu dari varietas padi dan termasuk family gramineae, tetapi mengandung kadar amilopektin yang tinggi (Suprio, 2017). Beras ketan hitam mempunyai warna ungu kehitaman yang mempunyai kandungan paling baik dibandingkan dengan beras berwarna lainnya. Komponen bioaktif yang terdapat dalam beras ketan hitam adalah antosianin. Antosianin merupakan pigmen ungu khas yang terkandung dalam beras ketan hitam dan sejumlah studi beberapa tahun belakangan menunjukkan bahwa antosianin memiliki beraneka manfaat diantaranya sebagai antioksidan, antiinflammatory, senyawa anti mikroba, memiliki aktivitas anti-karsinogenik, memperbaiki penglihatan, menginduksi apoptosis, efek neuroprotektif, berpengaruh terhadap pembuluh darah dan platelet sehingga meminimalkan resiko jantung koroner (Purnamasari, dkk 2016)

Madu adalah suatu zat kental manis yang dibuat oleh lebah dengan jalan fermentasi dari nektar bunga di dalam saluran pencernaan lebah setelah mengalami perubahan. Madu berkhasiat untuk menghasilkan energi, meningkatkan daya tahan tubuh dan meningkatkan stamina. Madu juga mengandung unsur makanan yang luar biasa walaupun kadarnya kecil sehingga bisa digunakan sebagai tonik alami. Keunggulan lain yang dimiliki madu adalah aroma dan cita rasa yang khas, maka madu sering digunakan untuk penyedap makanan, bahan kosmetik dan obat-obatan

Bodyscrub adalah salah satu produk yang merupakan hasil dari perkembangan teknologi yang cepat saat ini, lulur bodyscrub digunakan untuk menjaga kebersihan dan kesegaran kulit tubuh, produk bodyscrub sangat bervariasi mulai dari harga, warna kemasan, kelembutan tekstur dan aroma. Penggunaan bodyscrub bertujuan untuk mengangkat sel-sel kulit mati, kotoran dan membuka poripori sehingga kulit menjadi lebih cerah dan putih. Sekarang ini begitu banyak jenis lulur yang beredar dimasyarakat dengan berbagai khasiat dimulai dari menghaluskan kulit, meremajakan kulit hingga memutihkan kulit.

Selama ini beras ketan hitam hanya dimanfaatkan sebagai bahan dalam olahan makanan, padahal menurut beberapa literature ketan hitam selain bermanfaat untuk kesehatan juga memiliki manfaat bagi kecantikan kulit seperti melembabkan kulit, mencerahkan kulit, mengangkat sel kulit mati dan menggantikannya dengan sel kulit baru yang lebih sehat, mendinginkan kulit, membantu merawat peremajaan kulit serta menghaluskan kulit. Sehingga pada penelitian ini akan dilakukan kajian pemanfaatan beras ketan hitam sebagai bahan dasar pembuatan bodyscrub dari beras ketan 
hitam dan madu, dimana scrub memiliki sifat yang dapat mengangkat kotoran pada kulit, beras ketan hitam dapat digunakan untuk kulit yang kering serta dengan penambahan madu dapat digunakan untuk kulit yang berkeriput. Sehingga fungsi dari bodyscrub berbahan dasar beras ketan hitam dan madu ini diformulaskan untuk menghilangkan kulit mati dan memberikan kesan lembut dan segar pada kulit. Tujuan dilakukannya penelitian ini yaitu untuk menentukan formulasi terbaik pada pembuatan bodyscrub berbahan dasar beras ketan hitam dan madu.

Berdasarkan studi pustaka, Musdalipah (2016) telah melakukan penelitian yang berjudul "Formulasi BodyScrub Sari Ubi Jalar Ungu (Ipomoea Batatas L.) Varietas Ayamurasaki". Penelitian tersebut bertujuan untuk memformulasikan sari ubi jalar ungu (Ipomoea batatas L.) varietas ayamurasaki pada konsentrasi formula A 40\%, formula B 45\%, dan formula C 50\%. Jenis penelitian adalah eksperimen. Pengujian sediaan meliputi uji homogenitas, uji $\mathrm{pH}$, uji organoleptik, uji iritasi, dan uji tipe emulsi. Sari diperoleh dengan cara sampel diparut hingga halus, setelah halus diperas menggunakan kain flanel sehingga diperoleh sari ubi jalar ungu. Hasil penelitian menunjukkan sediaan yang dibuat memenuhi evaluasi fisik sediaan yaitu tekstur semipadat, bau khas, warna cokelat, homogen, tipe emulsi minyak dalam air, pH berkisar antara 6,1-6,2, dan tidak mengiritasi. Sediaan bodyscrub yang baik digunakan ialah formula B $45 \%$.

Kemudian Kanza (2016) melakukan penelitian tentang formulasi bodyscrub dari ampas kopi dengan bahan pengikat berupa tepung beras. Penelitian ini bertujuan untuk mendapatkan formulasi terbaik dari produk bodyscrub ampas kopi. Produk terbaik dihasilkan dari formulasi persentase scrub 5\% dan dapat menghasilkan body scrub bermutu baik dengan umur simpan 9 bulan serta disukai 80\% panelis. Namun penelitian menunjukkan bahwa penggunaan tepung beras sebagai bahan pengikat kurang efektif, dan pada penelitian selanjutnya disarankan untuk mengganti menjadi bahan lain yang memiliki kemampuan emulsifier yang lebih baik.

Suprio (2017) melakukan penelitian pembuatan lotion gel berbasis beras ketan hitam dan madu. Hasil penelitian menunjukkan bahwa bentuk gel yang diperoleh berbentuk setengah padat sesuai dengan literatur dan memiliki bau khas dari ekstrak beras ketan hitam (Oryza sativa var glutinous). Ekstrak beras ketan hitam berperan untuk memberikan efek anti-kerut terhadap sediaan gel yang dihasilkan. Pada tahun yang sama, Lestari, dkk (2017) melakukan penelitian yang betujuan untuk memformulasikan lulur bodysrub dengan arang aktif dari cangkang kelapa sawit. Hasil penelitian menunjukkan bahwa untuk sedian dengan menggunakan arang aktif mampu efektif untuk melakukan detofsifikasi.

Pengembangan produk body scrub dari beras ketan hitam menjadi hal yang baru untuk diteliti sehingga perlu dilakukan formulasi. erdasarkan pemaparan di atas, maka tujuan pada penelitian ini adalah menentukan formulasi terbaik pada pembuatan bodyscrub berbahan dasar beras ketan hitam dan madu berdasarkan parameter sifat fisik organoleptik (warna, aroma dan tekstur), kelembapan kulit, iritasi kulit, $\mathrm{pH}$ dan stabilitas emulsi.

\section{METODOLOGI PENELITIAN}

\section{A. Alat dan Bahan}

Alat dan bahan yang digunakan dalam penelitian ini yaitu: ayakan, baskom, blender, neraca analitik, gelas beaker, spatula, hot plate, gelas ukur, thermometer, cawan petri, sendok sudip dan pipet ukur, beras ketan hitam, madu, cetyl alkohol, asam stearat, gliserin, trietanolamin, propilen glikol, silika dan kertas $\mathrm{pH}$.

\section{B. Prosedur Percobaan}

Pembuatan lulur bodyscrub diawali dengan beras ketan hitam diblender hingga menjadi tepung ketan hitam, tepung ketan diayak sehingga didapatkan tepung ketan yang halus. Kemudian pembuatan basis sediaan bodyscrub dilakukan dengan melakukan tahap pencampuran. Bahan yang dicampur dibagi menjadi bahan water base dan bahan oil base, bahan oil base terdiri dari setil alkohol 1 gram dan asam stearat 15 gram yang dimasukkan kedalam gelas beaker $250 \mathrm{ml}$ dan dipanaskan diatas hotplate pada suhu $70-75^{\circ} \mathrm{C}$ hingga melebur. Bahan water base terdiri dari akuades $100 \mathrm{ml}$, propilen glikol $5 \mathrm{ml}$, gliserin $5 \mathrm{ml}$ dan trietanolamin (TEA) 1,2 $\mathrm{ml}$ yang diaduk serta dipanaskan hingga 75$80^{\circ} \mathrm{C}$. Setelah tersedia bahan water base dan bahan oil base, bahan water base dimasukkan kedalam bahan oil base dan diaduk secara perlahan. Pencampuran bahan scrub dilakukan setelah terbentuk 
terbentuk basis basis krim yang mengental kemudian ditambahkan silika sebanyak 2 gram. Pada tahap pencampuran, bodyscrub diberi perlakuan persentase tepung ketan halus yaitu 1,53\%, 3,07\% dan 4,6\%. Dasar persentase penambahan beras ketan hitam, didasarkan pada perbedeaan satuan komposisi yang digunakan sehingga untuk menyamakan satuan itu, maka komposisi total dikonversi ke dalam gram, sehingga penambahan jumlah beras ketan hitam dan madu mengikuti satuan komposisi total yang dipersentasekan dalam gram total komposisi. Tiap formulasi ditempatkan pada wadah bodyscrub, diberi etiket dan siap untuk dianalisis.

Tabel 1. Formulasi Beras Ketan Hitam dan Madu

\begin{tabular}{lccc}
\hline \multicolumn{1}{c}{ Bahan } & F1 & F2 & F3 \\
\hline Aquades & $100 \mathrm{ml}$ & $100 \mathrm{ml}$ & $100 \mathrm{ml}$ \\
Setil alkohol & $1 \mathrm{gram}$ & $1 \mathrm{gram}$ & $1 \mathrm{gram}$ \\
Asam stearat & $15 \mathrm{gram}$ & $15 \mathrm{gram}$ & $15 \mathrm{gram}$ \\
Propilen glikol & $5 \mathrm{ml}$ & $5 \mathrm{ml}$ & $5 \mathrm{ml}$ \\
Gliserin & $5 \mathrm{ml}$ & $5 \mathrm{ml}$ & $5 \mathrm{ml}$ \\
Triethanolamin & $1.2 \mathrm{ml}$ & $1.2 \mathrm{ml}$ & $1.2 \mathrm{ml}$ \\
Silika & $3 \mathrm{gram}$ & $3 \mathrm{gram}$ & $3 \mathrm{gram}$ \\
Madu & $1,53 \%$ & $3,07 \%$ & $4,6 \%$ \\
Beras ketan & $1,53 \%$ & $3,07 \%$ & $4,6 \%$ \\
\hline
\end{tabular}

\section{Pengujian Sifat Fisik}

Pengujian sifat fisik yang dilakukan pada penelitian ini yaitu uji organoleptik (warna, aroma dan tekstur), uji $\mathrm{pH}$, uji iritasi kulit, uji tingkat kelembapan kulit dan uji stabilitas emulsi.

\section{Uji Organoleptik}

Uji organoleptik dilakukan dengan cara membagikan check sheet kepada 30 orang panelis lembaran tersebut berisikian data pribadi dan uji yang harus diisi, adapun yang harus diisi yaitu pada uji warna, pada uji warna peneliti mencari data dengan mengunakan aplikasi inkscape. Adapun kode warna yang ditunjukkan yaitu purple, mauve, violet, lavender, periwinkle, heather, amethyst, orchid dan lilac. Uji aroma dilakukan dengan panelis mencium aroma dan mengkaitkannya dengan parameter skala yang sudah ditentukan, adapun skala yang sudah ditentukan pada uji aroma yaitu skala 1 tidak berbau ketan hitam dan madu, skala 2 sedikit berbau ketan hitam dan madu, skala 3 berbau ketan hitam dan madu, skala 4 lebih tercium aroma ketan hitam dan madu serta skala 5 sangat tercium aroma ketan hitam dan madu. Pengujian tekstur dilakukan dengan cara mengambil bodyscrub kemudian digosokkan kearea lengan tangan dan dirasakan scrub yang dirasakan pada saat menggosokkan bodyscrub kelengan tangan, skala yang digunakan dalam pengujian tekstur yaitu skala 1 tidak ada butiran scrub, skala 2 sedikit ada butiran scrub, skala 3 ada butiran scrub, skala 4 lebih banyak butiran scrub dan skala 5 sangat banyak butiran scrub (Ulfa, dkk 2016).

\section{Uji pH}

Uji pH dilakukan untuk melihat tingkat keasaman sediaan scrub untuk menjamin sediaan scrub tidak menyebabkan iritasi pada kulit. $\mathrm{pH}$ sediaan scrub diukur dengan menggunakan stik $\mathrm{pH}$ universal. Stik pH universal dicelupkan kedalam sampel scrub yang telah diencerkan, didiamkan beberapa saat dan hasilnya disesuaikan dengan standar $\mathrm{pH}$ universal. Pengujian $\mathrm{pH}$ dilakukan untuk mengetahui nilai keasaman dari sediaan kosmetik. Berdasarkan SNI 16-4399-1996 bahwa nilai pH produk kosmetik kulit disyaratkan berkisar antara 4,5-8,0 (Andriyanto, 2010).

\section{Uji Iritasi Kulit}

Uji iritasi kulit dilakukan untuk mengetahui seberapa besar pengaruh ukuran partikel bodyscrub yang dibuat terhadap iritasi kulit yang ditimbulkan oleh masing-masing formula yang diujikan. Pengujian dilakukan dengan cara mengoleskan bodyscrub pada lengan bawah terhadap 30 orang panelis. Reaksi yang diamati adalah terjadinya iritasi pada kulit atau tidak. Reaksi iritasi positif ditandai oleh adanya kemerahan, gatal-gatal, atau bengkak paa kulit lengan bawah bagian dalam yang 
diberi perlakuan, adanya diberi tanda (+), gatal-gatal (++), bengkak (+++) dan yang tidak menunjukkan reaksi diberi tanda (-). Uji ini dilakukan selama 15 menit (Sari, 2012).

\section{Uji Kelembaban Kulit}

Pengujian nilai kelembaban kulit dilakukan dengan cara mengukur nilai hidrasi pada lapisan kulit yang paling luar. Kadar air dalam lapisan luar kulit normal sekitar 10\% dan pada lapisan dalam sekitar 30\%. Pengujian ini dilakukan dengan menggunakan alat yaitu skin analyzer, alat ini akan mendeteksi kadar air dan minyak pada kulit yang diuji (Junardy, dkk. 2009).

\section{Uji Stabilitas Emulsi}

Uji stabilitas dilakukan dengan cara menimbang cawan petri yang masih kosong kemudian dicatat dan dimasukkan sampel bodyscrub sebanyak 5 gram lalu dimasukkan kedalam oven dengan suhu $45^{\circ} \mathrm{C}$ selama satu jam, setelah satu jam kemudian dimasukkan sampel kedalam mesin pendingin bersuhu dibawah $0^{\circ} \mathrm{C}$ selama satu jam. Setelah satu jam, cawan petri beserta sampel kemudian ditimbang untuk dilakukannya perhitungan (Putri, 2009).

Stabilitas emulsi $=\frac{\text { berat } f \text { ase tersisa }}{\text { berat awal sampel }} \times 100 \%$

\section{HASIL DAN PEMBAHASAN}

Produk bodyscrub dari beras ketan hitam dan madu disediakan dalam bentuk krim scrub (Gambar 1). Sediaan krim dipilih karena bodyscrub lebih mudah untuk diaplikasikan ke area tubuh sehingga krim cepat menyerap kedalam kulit, krim merupakan tipe emulsi berjenis minyak dalam air (Larasati, 2016). Fraksi minyak berupa asam stearat dan setil alkohol sedangkan fraksi air berupa akuades, gliserin, propilen glikol dan trietanolamin (TEA). Asam stearat dan setil alkohol merupaan fraksi minyak padat yang berfungsi sebagai pembentuk sediaan krim sebagai emulgator dan stiffening agent. Propilen glikol dan gliserin merupakan fraksi air yang berfungsi sebagai humektan sedangkan trietanolamin (TEA) digunakan sebagai emulsifier dan surfaktan sebagai penstabil $\mathrm{pH}$ pada produk kosmetik. Tujuan dibuatnya produk bodyscrub yaitu untuk membantu mengangkat sel kulit mati yang tidak terangkat oleh sabun dengan maksud memperbaiki penampilan kulit sehingga kulit menjadi lebih bersih dan sehat (Andriyanti, dkk, 2010).
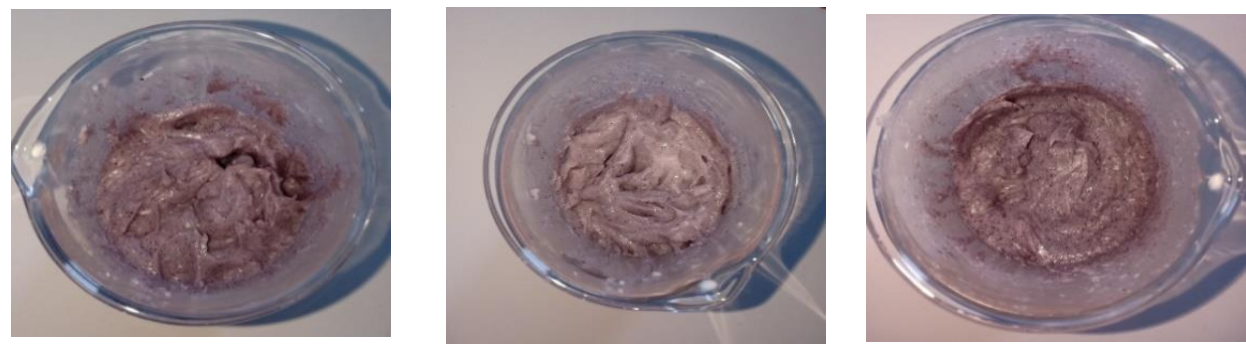

Gambar 1. Produk Bodyscrub

\section{A. Uji Organoleptik}

Uji organoleptik yang dilakukan meliputi uji warna, aroma serta tekstur. Hasil uji organoleptik menunjukkan warna yang dihasilkan oleh bodyscrub berwarna mauve seperti yang disajikan pada Tabel 2. Sesuai dengan warna zat aktif beras ketan hitam yaitu ungu, memiliki bau yang khas dari beras ketan hitam dan memiliki tekstur yang lembut dan banyak mengandung scrub.

\section{B. Warna}

Berdasarkan data hasil pengamatan pada skala warna (Tabel 2), hasil perlakuan beras ketan terhadap produk bodyscrub menunjukkan hasil yang terbaik yaitu pada perlakuan A3 dengan hasil RGB yaitu 140113120 yang memiliki kode warna yaitu RGBA 704d51ff, data tersebut didapatkan dengan menggunakan aplikasi inkscape. Warna ini dihasilkan dari karakteristik warna beras ketan hitam yaitu ungu pekat atau ungu kehitaman sehingga ketika tepung beras ketan hitam yang 
ditambahkan kedalam sediaan krim lebih banyak maka warna yang dihasilkan akan semakin kewarna ungu kehitaman. Kandungan warna ungu yang terdapat didalam beras ketan hitam (oryza sativa glutinosa) didapatkan dari sel-sel pada kulit ari yang mengandung antosianin. Antosianin merupakan pigmen yang memiliki warna merah, ungu dan biru, sehingga zat antosianin ini yang mempengaruhi warna bodyscrub sehingga bodyscrub memiliki warna ungu (Suhartatik et al., 2013).

Tabel 2. Data Hasil Pengamatan Warna Produk Bodyscrub

\begin{tabular}{|c|c|c|c|}
\hline Sampel & Gambar & Warna (RGB) & RGBA \\
\hline A1 & & 200172169 & $\begin{array}{c}\text { C8ACA9 } \\
\text { (Periwinkle) }\end{array}$ \\
\hline $\mathrm{A} 2$ & & 132102102 & $\begin{array}{c}846666 \\
\text { (Mauve) }\end{array}$ \\
\hline A3 & & 1077078 & $\begin{array}{l}\text { 6B464E } \\
\text { (Mauve) }\end{array}$ \\
\hline
\end{tabular}

\section{Aroma}

Berdasarkan data hasil pengamatan pada skala aroma (Tabel 3), dimana hasil persentase paling tinggi pada formulasi A1 yaitu 36,66\% dari 30 panelis, yang berarti tidak tercium aroma yang khas dari beras ketan hitam. Pada sampel A2 dan A3 sama-sama memiliki hasil persentase tertinggi pada skala 2 yaitu sedikit tercium aroma yang khas dari beras ketan hitam dan madu akan tetapi persentase paling tinggi berada sampel A2 sebanyak $36,66 \%$ sedangkan pada sampel A3 persentasenya sebanyak $33,33 \%$ dari 30 panelis.

Tabel 3. Data Uji Aroma Produk Bodyscrub

\begin{tabular}{lccc}
\hline \multicolumn{1}{c}{ Penilaian } & \multicolumn{3}{c}{ Persentase } \\
\cline { 2 - 4 } & $\mathrm{A} 1$ & $\mathrm{~A} 2$ & $\mathrm{~A} 3$ \\
\hline Tidak berbau ketan hitam dan madu & 36,66 & 33,33 & 23,33 \\
Sedikit berbau ketan hitam dan madu & 26,66 & 36,66 & 33,33 \\
Berbau ketan hitam dan madu & 16,66 & 20 & 13,33 \\
Lebih tercium aroma ketan hitam dari pada madu & 20 & 10 & 20 \\
Sangat tercium aroma beras ketan hitam dan madu & 0 & 0 & 10 \\
\hline
\end{tabular}

Dari data diatas dapat dikatakan bahwa formulasi yang memiliki nilai tertinggi yaitu pada sampel A1 dan A2. Aroma yang dihasilkan pada bodyscrub berbahan dasar beras ketan hitam dan madu ini tergantung pada banyaknya persentase dari beras ketan hitam yang ditambahkan kedalam sediaan krim bodyscrub sehingga semakin banyak ditambahkan tepung beras ketan hitam dan madu maka semakin tercium aroma yang khas dari beras ketan hitam. 


\section{Tekstur}

Berdasarkan data hasil pengamatan pada skala tekstur (Tabel 4), dimana hasil persentase paling tinggi pada formulasi A1 yaitu 50\% dari 30 panelis yang menilai, tekstur yang dimiliki oleh sampel A1 yaitu sedikit ada butiran scrub yang dirasakan oleh panelis. Pada sampel A2 sebanyak 46,66\% dari 30 panelis yang menilai merasakan adanya butiran scrub, dan pada sampel A3 sebanyak $60 \%$ yang merasakan lebih banyak scrub yang terdapat pada sampel bodyscrub yang diujikan.

Tabel 4. Data Uji Tekstur Produk Bodyscrub

\begin{tabular}{lccc}
\hline \multicolumn{1}{c}{ Penilaian } & \multicolumn{3}{c}{ Persentase penilaian panelis (\%) } \\
\cline { 2 - 4 } & A1 & A2 & A3 \\
\hline Tidak ada butiran scrub & 10 & 0 & 0 \\
Sedikit ada butiran scrub & 50 & 26,66 & 16,66 \\
Ada butiran scrub & 30 & 46,66 & 13,33 \\
Lebih banyak butiran scrub & 6,66 & 26,66 & 60 \\
Sangat banyak butiran scrub & 3,33 & 0 & 10 \\
\hline
\end{tabular}

Adanya scrub yang dirasakan oleh panelis dikarenakan proporsi dari tepung ketan hitam yang ditambahkan kedalam sediaan bodyscrub berbeda, sehingga semakin banyak tepung beras ketan hitam yang ditambahkan maka semakin mempengaruhi tingkat kekasaran pada sediaan bodyscrub. Adanya silika yang ditambahkan kedalam sediaan bodyscrub dapat memberikan efek scrub yang ada pada sampel bodyscrub. Dari persentase tepung beras ketan hitam yang ditambahkan kedalaam sediaan krim bodyscrub dapat mempengaruhi tingkat kekasaran pada sediaan bodyscrub.

\section{E. Uji pH}

Nilai pH merupakan nilai yang dapat menunjukkan derajat keasaman suatu sediaan yang dapat diketahui melalui suatu indikator. Kulit memiliki mantel asam yang berfungsi melindungi kulit dari bakteri dan jamur. Pemakaian produk kecantikan yang memiliki $\mathrm{pH}$ yang jauh berbeda dengan $\mathrm{pH}$ fisiologis kulit akan merusak mantel asam kulit serta menimbulkan iritasi kulit (Andriyanti et al., 2010). Pengujian $\mathrm{pH}$ dilakukan dengan menggunakan alat parameter stik $\mathrm{pH}$ universal, nilai $\mathrm{pH}$ bodyscrub pada formulasi $2 \%, 4 \%$ dan 6\% yang dilakukan selama 5 hari menunjukkan nilai 7 yang berarti bodyscrub memiliki $\mathrm{pH}$ netral dan aman bagi kulit, hal ini dikarenakan fungsi dari trietanolamin (TEA) sebagai emulsifier dan surfaktan sebagai penstabil $\mathrm{pH}$ pada produk kosmetik.

Menurut (Andriyanti et al., 2010) sediaan kosmetik harus memiliki $\mathrm{pH}$ yang sesuai dengan $\mathrm{pH}$ kulit yaitu antara 4,5-7,5 sehingga hasil dari uji $\mathrm{pH}$ pada sediaan bodyscrub beras ketan hitam dan madu relatif aman untuk digunakan. $\mathrm{pH}$ yang terlalu basa dapat menyebabkan kulit bersisik sedangkan $\mathrm{pH}$ yang terlalu asam dapat menyebabkan iritasi kulit, maka dapat dikatakan bahwa dari ketiga sampel bodyscrub tidak menunjukkan adanya perbedaan nilai $\mathrm{pH}$.

\section{F. Uji iritasi kulit}

Uji iritasi kulit dilakukan untuk mengetahui pengaruh sampel bodyscrub terhadap iritasi yang ditimbulkan oleh masing-masing sampel yang diujikan, sehingga dapat diketahui tingkat keamanan dari masing-masing sampel. Dari ketiga sampel yang diujikan (Tabel 5), sampel A2 dan A3 sebanyak $60 \%$ dari 30 panelis tidak merasakan adanya iritasi yang disebabkan oleh sampel yang diujikan. Sebanyak $40 \%$ panelis merasakan panas saat mengoleskan sampel ke lengan bagian dalam, hal ini disebabkan karena trietanolamin (TEA) yang dapat menyebabkan reaksi alergi (Erungan, dkk, 2009).

Tabel 5. Data Uji Iritasi Kulit Terhadap Produk Bodyscrub

\begin{tabular}{lccc}
\hline \multirow{1}{*}{ Penilaian } & \multicolumn{3}{c}{ Persentase penilaian Panelis (\%) } \\
\cline { 2 - 4 } & $\mathrm{A} 1$ & $\mathrm{~A} 2$ & $\mathrm{~A} 3$ \\
\hline Tidak ada reaksi & 46,66 & 60 & 60 \\
Panas & 40 & 23,33 & 26,66 \\
Gatal-gatal & 13,33 & 16,66 & 13,33 \\
Bengkak & 0 & 0 & 0 \\
\hline
\end{tabular}




\section{G. Uji kelembaban kulit}

Data hasil uji kelembaban kulit menunjukkan bahwa formulasi terbaik yang memiliki nilai kelembapan kulit paling tinggi yaitu pada formulasi A3 sebesar 18,60\% dari nilai kelembapan kulit kontrol sebesar 16,58\%. (Tabel 6). Hal ini dikarenakan ketan hitam mengandung antioksidandan juga pelembab alami yang dapat melindungi kulit serta kandungan squalane oil yang berfungsi untuk melembabkan dan penambahan madu juga berfungsi untuk melembabkan kulit sehingga dari kombinasi kedua bahan tersebut kulit akan mengalami kenaikan angka kelembapan kulit sehingga kulit akan menjadi sehat dan lembap. Menurut (Yumas, 2016) Kulit lembab memiliki kandungan air yang cukup sehingga sel-sel kulit dapat secara optimal untuk menjaga fungsinya. Hal yang berperan dalam menjaga kelembaban kulit adalah asupan air minum yang cukup dan fungsi lapisan lemak kulit yang mempertahankan air pada lapisan kulit, lapisan lemak ini terletak dibawah sel kulit yang paling atas.

Tabel 6. Data uji kelembapan kulit

\begin{tabular}{ccccc}
\hline Nilai rata-rata sebelum & \multicolumn{4}{c}{ Nilai rata-rata sesudah menggunakan bodyscrub (\%) } \\
\cline { 2 - 5 } menggunakan bodyscrub (\%) & Kontrol & A1 & A2 & A3 \\
\hline 12,89 & 16,58 & 17,22 & 18,14 & 18,60 \\
\hline
\end{tabular}

\section{H. Uji Stabilitas Emulsi}

Stabilitas emulsi menunjukkan kestabilan suatu bahan dimana emulsi yang terdapat dalam bahan tidak mempunyai kecenderungan untuk bergabung dengan partikel lain dan membentuk lapisan yang terpisah, emulsi yang baik mempunyai sifat tidak berbuah menjadi lapisan-lapisan. Hasil pengujian stabilitas emulsi pada bodyscrub berbahan dasar beras ketan hitam dan madu dapat dilihat pada Gambar dibawah ini.

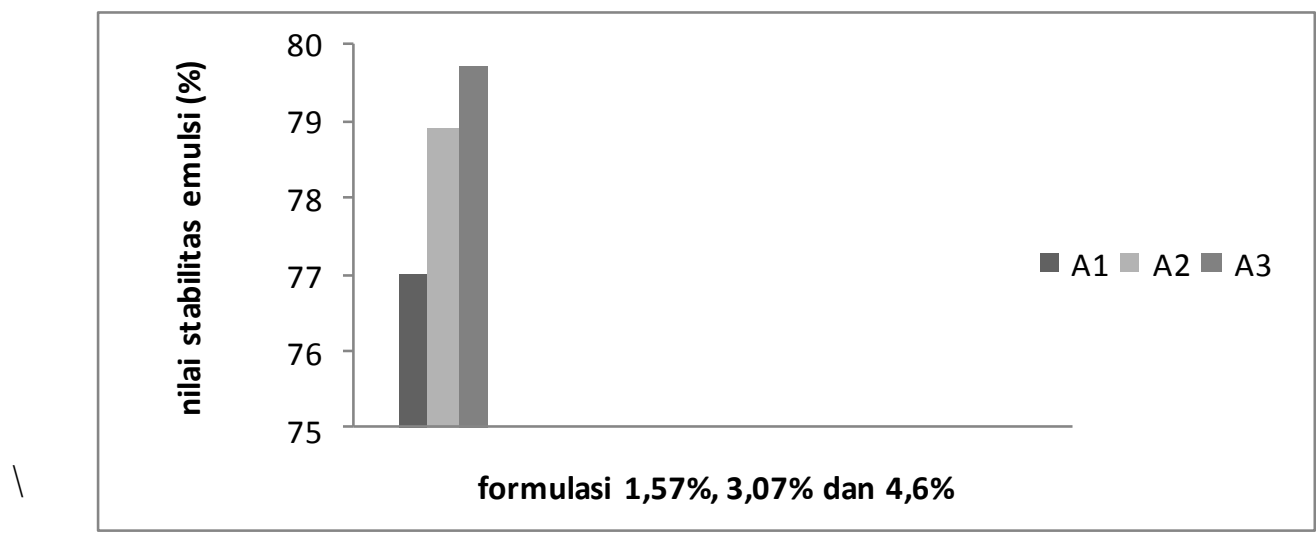

Gambar 2. Nilai Stabilitas Emulsi

Hasil pengujian stabilitas emulsi bodyscrub berbahan dasar beras ketan hitam dan madu berkisar antara 77-80 \%. Hasil pengujian ini menunjukkan bahwa stabilitas emulsi pada sampel bodyscrub tidak stabil, hal ini dikarenakan stabilitas emulsinya tidak mencapai $100 \%$. Menurut Purwaningsih (2014), tidak stabilnya emulsi pada bodyscrub akan mengakibatkan perubahan kimia dan fisika, perubahan kimia yang dapat terjadi yaitu perubahan warna dan aroma sedangkan perubahan fisika yang dapat terjadi yaitu pemisahan fase. Stabilitas emulsi pada bodyscrub beras ketan hitam dan madu dipengaruhi oleh beberapa faktor yaitu faktor mekanis, temperatur dan ketidakstabilan pada saat proses pengadukan.

\section{KESIMPULAN}

Formulasi terbaik produk bodyscrub yaitu penambahan beras ketan hitam dan madu sebesar 4,6\% dengan karakteristik warna mauve, aroma sedikit berbau beras ketan hitam dan madu, tekstur lebih banyak butiran scrub, memiliki pH 7, tidak menyebabkan iritasi kulit, dapat melembabkan kulit serta memiliki kestabilan emulsi yang baik. 


\section{DAFTAR PUSTAKA}

Amalliyah, B. 2014. Stabilitas Fisika Sediaan Bodyscrub Mengandung Bekatul, Rice Bran Oil, Virgin Coconut Oil (VCO), Kopi dan Ekstrak Aloe Vera dengan Bahan Pengawet Dmdm Hydantoin dan Natrium Benzoat. Ilmiah, 3(1), 1-16.

Andriyanti, P., Indriati, D., \& Wardatun, S. 2010. Uji Antioksidan Sediaan Sugar Body Scrub yang Mengandung Katekin Gambir (Uncaria Gambir (Hunter) Roxb) dan Essensial Oil Jeruk Nipis (Citrus Aurantifolia L.) dengan Metode Dpph. Farmasi Fakultas Matematika dan Ilmu Pengetahuan Alam.

Erungan, Anna Carolina, Purwaningsih, S., \& Anita, Syeni Budi. 2009. Aplikasi Karaginan dalam Pembuatan Skin Lotion Application. Fakultas Perikanan dan Ilmu Kelautan Institut Pertanian Bogor, XII(2), 128-143.

Harefa, Reni Ester Pertiwi. 2018. Formulasi dan Uji Efektivitas Sediaan Krim Body Scrub yang Mengandung Ampas Kopi (Coffea arabica L.). Skripsi Universitas Sumatera Utara. http://repositori.usu.ac.id/handle/123456789/11782.

Kusumaningrum, Ayu Anggraini, \& Widayati, Retno Indar. 2017. Efektivitas Macadamia Oil 10\% dalam Pelembab pada Kulit Kering. Jurnal Kedokteran Diponegoro Volume, 6(2), 347-356.

Larasati, D. 2016. Perbandingan Tepung Beras Ketan Putih (Ci Asem) dengan Tepung Beras Ketan Hitam (Setail) dan Konsentrasi Buah Murbei (Morus Nigra.L) terhadap Karakteristik Opak Ketan Hitam. Universitas Pasundan Bandung.

Purnamasari, V., Pakki, E., \& Mirawatai. 2016. Formulasi Lulur Krim Yang Mengandung Kombinasi Yoghurt Dan Pati Beras Hitam (Oryza Sativa L.). Farmasi, 08(02), 83-91.

Suhartatik, N., Karyantina, M., Mustofa, A., Cahyanto, muhammad nur, Raharjo, S., \& Rahayu, endang sutriswati. 2013. Stabilitas Ekstrak Antosianin Beras Ketan (Oryza Sativa Var. Glutinosa) Hitam Selama Proses Pemanasan dan Penyimpanan. Agritech, 33(4), 384-390.

Suprio, H. W. 2017. Pemanfaatan Beras Ketan Hitam (Oryza Sativa L. Indica) dan Madu sebagai Bahan Dasar Pembuatan Lotion Gel. Media Farmasi, XIII(2), 105-110.

Ulfa, M., Khairi, N., \& Maryam, F. 2016. Formulasi dan Evaluasi Fisik Krim Body Scrub dari Ekstrak Teh Hitam (Camellia sinensis), Variasi Konsentrasi Emulgator Span-Tween 60. JF FIK UINAM, 4(4), 179-185. 